\title{
The Scale of Evaluating Instruction in Pandemic Process: Development, Validation, and Reliability
}

Özgür Tutal ${ }^{1}$, Bünyami Kayalı ${ }^{2}$ Mehmet Yavuz ${ }^{3}$, Mehmet Hasançebi', Funda Yeşildă̆-Hasançebi ${ }^{5}$

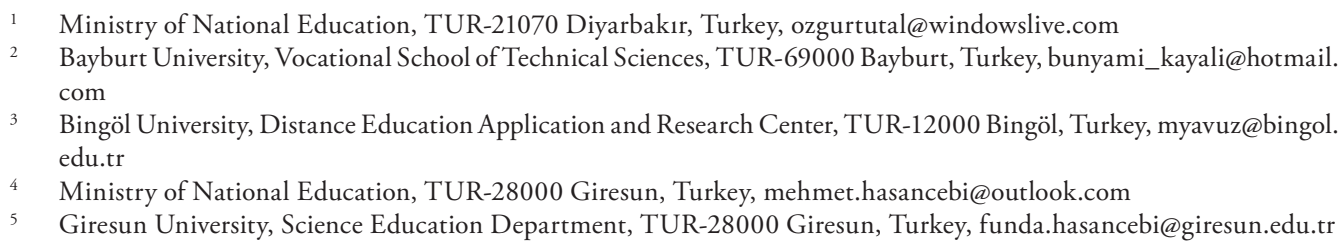

Annotation. The study aims to develop a scale for determining student views on distance instruction, hybrid instruction, and back-to-school process after the pandemic. The study data were obtained from 442 students. EFA and CFA were performed to determine the scale's construct validity. Moreover, to decide the data collection tool's reliability, item analysis was conducted and internal consistency coefficients were estimated. Based on the results obtained from the validity and reliability analysis of the scale, it can be said that the Scale of Evaluating Instruction in Pandemic Process (SEIPP) is valid and reliable.

Keywords: coronavirus (COVID-19), pandemic, distance instruction, back-to-school, hybrid instruction, scale development.

\section{Introduction}

With the COVID-19 pandemic, the whole world has had to face a never-before-seen major disaster that affected almost all countries. The pandemic has negatively affected every aspect of life and brought life to a standstill. In this process, just as the economy, health system, social and individual life, the education system was deeply affected. 
According to UNESCO (2020), since April 2020 schools in 193 countries around the world have been wholly or partially closed. Approximately two billion students and 63 million teachers have been directly or indirectly affected by this process. In order to continue the education process during the pandemic period, to minimize learning losses, and primarily to ensure that students cope with the adverse effects of the pandemic, countries have decided to continue their educational activities through distance instruction. The countries carried out distance education in line with their technological infrastructure; printed teaching materials, radio and television broadcasts, internet-based online and offline activities (Aydın, 2020; Merfeldaite, Prakapas \& Railienė, 2020).

The failure to control the pandemic in many parts of the world, especially in Europe, and the lack of positive news about the vaccine during the year showed that the pandemic process would take longer than expected. For this reason, how distance education activities will continue has been a matter of curiosity. Particularly as the schools' starting dates approached, there were heated discussions about whether or not the schools should open with the increasing number of cases. Since some circles did not find the studies about children not being super-spreaders sufficient, they argued that schools' opening would contribute to the spread of the pandemic by increasing the number of cases. At this point, they stated that the concerns of parents and teachers should be taken into account (Puntis, 2020). On the other hand, some scientists advocated the opening of schools as soon as possible due to reasons such as the low risk of transmission in children, loss of education, psychological problems, domestic violence, lack of physical activity, and educational inequality (Tamburlini \& Marchetti, 2020; Rajmil, 2020). Especially many countries in Europe declared that, as a social priority, schools were excluded from these restrictions and face-to-face instruction would continue. Contrary to the expectation, as of September 2020, the number of countries that opened their schools partially or completely has increased to 143 , while this number has increased to 183 in November (TEDMEM, 2020). In Turkey, during the pandemic, instruction in primary, middle, and high schools was interrupted for the first time between March 16 and April 30, 2020. Later, it was announced that the instruction would be continued remotely, the grades of the first semester would be valid for the students to pass their classes, and they will pass to the upper level under any condition (Anadolu Agency, 2020). Within the scope of distance education applications, it has been decided to continue the education on 3 TV Channels (EBA TV) and Education Information Network (EBA). In addition, for students who do not have sufficient technological facilities such as internet access and computers, computer and internet facilities called EBA Support Points are provided in schools (Ministry of National Education, 2020a). After about six months, face-to-face instruction restarted in a gradual and reduced way in September and continued at different grade levels until the mid-term break in November when the schools closed completely (Ministry of National Education, 2020b). 
With schools' opening, the above-mentioned discussions did not end; they changed direction to focus on the children's safe return to school. However, to prevent inequalities in education and to minimize the parents' anxiety; minimizing the risk to children, maximizing the educational potential in schools, and prioritizing the benefits of the school in terms of children's psychological well-being are, in general, the main expectations of society from policymakers and school administrators (Woodland et al., 2020). In addition, it has been observed that the process has different concerns in terms of health, economy, and education for both teachers and students (Karakaya, Adıgüzel, Üçüncü, Çimen, \& Yilmaz, 2020). Upon examining the literature, research shows that the pandemic period brought to the forefront our need to confront the fact that education requires fundamental reforms and strategic planning (Bozkurt, 2020; Can, 2020). Therefore, it is vital to determine how the education system is affected by this process and its condition. In order to understand this situation, many measurement tools have been developed in different countries.

The "Back-to-School Surveys" prepared by Panorama Education (2020) aimed to reveal students, families, teachers, and administrators' opinions about returning to school after the pandemic. Woodland et al. (2020) conducted a study to determine the parents' disposition to send their children to school during the COVID-19 outbreak. Also, different survey and questionnaires have been generated to examine the view and experiences of parents (Brom et al., 2020; Dong, Chao \& Li, 2020; Garbe, Ogurlu, Logan \& Cook, 2020), teachers (Mailizar, Almanthari, Maulina \& Bruce, 2020), university members and students (Adnan \& Anwar, 2020; Alawamleh, Al-Twait \& Al-Saht, 2020; Aucejo, French, Araya \& Zafar, 2020; Barton, 2020; Demuyakor, 2020; Essilfie, Hurley, Strauss \& Alaia, 2020; Guo et al., 2020; Marinoni, Van't Land \& Jensen, 2020; Paudel, 2021; Shahrvini, Baxter, Coffey, Macdonald \& Lander, 2021; Shawaqfeh et al., 2020; Yllmaz-İnce, Kabul \& Diler, 2020) and medical residents (Chang, et al. 2020; Robbins et al., 2020) during the COVID-19 pandemic. However, as far as we know, no scale has yet been developed to determine middle and high school students' opinions about instruction during the pandemic process.

As a result, some practices (such as open and distance education, blended learning) have been implemented in Turkey as well as all over the world not to disrupt the education system. Distance education is an education system where the teacher and the learner are in different places and times, in a planned learning environment, teaching is carried out with printed or electronic material (Gökmen, Duman \& Horzum, 2016; Moore, 1990). Distance learning is a contemporary and effective form of learning that can be presented regardless of place and time, and that educational materials can be configured in an electronic environment in an appropriate and flexible manner, updated and supported by different technologies (Yamamoto \& Altun, 2020). Blended learning is a learning model that combines online and face-to-face education applications, combining the advantages of distance learning with the benefits of traditional learning style (Korucu \& Kabak, 2020; Liu, Zang, Ye \& Wu, 2020). During crisis (earthquake, flood, epidemic), the necessity 
of hybrid applications which are supported by digital platforms in order to ensure the continuity of education and training have come to the fore (Korucu \& Kabak, 2020). However, not only the quantitative dimension of these practices but also their quality and the improvement of their effectiveness became a priority (Can, 2020). For this reason, it is critical to evaluate the practices and determine their effects on students because it is believed that these evaluations can contribute to the process of improvement by, taking measures, and generating alternatives for future applications. In this context, it is crucial to evaluate the distance, face-to-face, hybrid instruction, and back-to-school processes in the view of students during the crisis period (pandemic); in terms of meeting the expectations of the education system, minimizing uncertainty and anxiety, maximizing education potential, and helping education planners. Also, the fact that there are no studies on back-to-school after the pandemic and the existence of measurement tools developed for this purpose will help increase the number of such studies is another relevant matter. Based on this point, the current study aimed to develop a scale that makes it is possible to determine student views on distance instruction (TV broadcast, live lesson) carried out during the COVID-19 pandemic period, hybrid instruction (distance and face-to-face instruction) conducted afterwards, and the back-to-school process (practices, measures, the attitude of teachers and administrators, etc. during the pandemic process in the school) after the pandemic for middle and high school students.

\section{Method}

The measurement tool, consisting of 39 items, aimed to determine middle and high school students' opinions on distance instruction, hybrid instruction, and the new backto-school process during the COVID-19 pandemic. It was developed following the principles of scale development, which is a process of developing a reliable and valid measure of a structure on account of the estimate of an attribute of interest (Tay \& Jebb, 2017).

\section{Participants}

Participants of the present study were determined by convenience sampling (Yıldırım \& Şimşek, 2011) method. The study data were obtained from students studying at middle and high schools in Diyarbakır, Giresun, and Bayburt provinces (in schools where the second, third and fourth author served) in 2020-2021. When determining the sample size, it was observed that there were various claims on this subject in the literature. For instance, Kline $(1994 ; 2015)$ states that claims for participants' ratio to items range from 10:1 to 2:1. Also, according to his experience, a ratio of 3:1 gave loadings the same to those with a ratio of 10:1, and with 2:1 ratio samples, large factors emerge clearly. He also states that a sample size of 100 will be sufficient in the data with a clear factor structure. According to another point of view, Büyüköztürk (2011) states that the sample size 
should be at least five times the number of items, while Gable and Wolf (1993) argues that this ratio should be between 6 and 10 times. On the contrary, Tabachnick and Fidell (2014) mention that 300 is a good sample size. Given all these views, it was decided that a sample size of about ten times the number of items would be adequate for the current research. Thus, data were collected from 442 participants, while 45 items were found in the scale's initial form.

Three hundred forty-five (78\%) participants were students at middle school, and 97 (22\%) were at high school. 195 (44\%) of the participants were from cities, 235 (53\%) from districts, and 12 (3\%) from villages. When the gender distribution was examined, 257 (58\%) of the participants were girls, and $185(42 \%)$ were boys. The grade level of the students was as follows: 61 (13\%) fifth grade, 30 (7\%) sixth grade, 99 (22\%) seventh grade, 156 (35\%) eight grade students, 35 (8\%) freshmen, 30 (7\%) juniors, 11 (2\%) seniors and $20(5 \%)$ sophomores. While the number of participants who had access to the internet was 368 (83\%), the number of those who did not was 74 (17\%). Besides, the number of students participating in distance instruction through TV broadcasts was $71(16 \%)$, the number of those participating online was 196 (44\%), and the number of those participating both through TV broadcasts and online was 175 (40\%).

\section{Instrument and Procedure}

The process of scale development was started by the item pooling phase to determine the items that are candidates for eventual inclusion in the scale. Although it was limited, the related literature was initially reviewed. Next, each of the authors prepared their items on distance instruction, hybrid instruction, and the post-pandemic back-toschool process. Afterwards, three discussion meetings with all of the authors were held to review the prepared items and generate the initial draft form. In its first version, the form had 47 items. While some of the items were about the extent to which participants agreed with a judgment, some were about how often an event occurred. Therefore, the five-point Likert-type response options were composed in two different ways according to the items' characteristics. Answer options for the items in the first part were "strongly disagree", "disagree", "undecided", "agree" and "strongly agree", while the answer options for the second part were "never", "rarely", "occasionally", "often" and "always". The options' scoring was also determined from 1 to 5 (from the most negative to the most positive). In the next step, the draft form items were presented to the expert review for establishing the content validity. Experts were asked for their ideas if each item was "appropriate", "partly appropriate" or "not appropriate". They were wanted to write their suggestions if they checked "partly appropriate" or "not appropriate" options. The review of two experts in the Department of Curriculum and Instruction and an expert in the Department of Science Education (who have already developed scale) was obtained about the items. While it was decided to exclude two items from the form based on the experts' 
feedback, 12 items were revised. Thus, a 45-item draft scale was prepared for statistical validity-reliability analysis and used in the pilot study.

Fifty students (Şeker \& Gençdoğan, 2006), 32 of whom from middle school and 18 of whom from a high school participated in the pilot study which was conducted to determine whether the items in the draft scale generated would be understood in the same way by all participants. In the pilot study conducted by two authors, the items in the draft scale were read aloud by each participant, and the participants were then asked to explain what they understood from what they read. All of the participants stated that they understood the items and made similar explanations about the items. The data used in the pilot study were not used in other analyzes of the research. The scale, which was put into final form with the pilot study, was put into implication after the Giresun University ethics committee's approval. The introduction part of the scale stated that participation was voluntary, and the answers would be anonymous. Also, a statement containing the purpose of the research, the student's rights as participants, and the instructions on how to complete the scale are included here. The researchers collected the data on the scale via Google forms, as schools were in the distance instruction process.

\section{Data Analysis}

Prior to the data analysis, the data set was examined to determine whether there were missing data and outliers. As a result of the examination, it was determined that there was no missing data. For detecting outliers, each participant's total scores were ordered linearly, and for standardizing the total scores, $\mathrm{Z}$ values for each estimated. Subsequently, the standard deviation $(S D)$ of the distribution and the differences between the ordered $Z$ values were calculated. Then, all of the differences were found to be lower than the $S D$ (1) of the distribution. So it was realized that none of the scores were outliers. In addition, to establish whether the data set is normally distributed or not, the skewness and kurtosis coefficients and normal q-q plot were examined. Item analyzes of the scale were conducted utilizing the item-total correlations (Erkuş, 2014) and the difference between the lower and upper group averages (Tezbaşaran, 2008).

The expert review was used to ensure content validity. For the structure validity, primarily Exploratory Factor Analysis (EFA) was utilized to reveal the scale's implicit structure and determine the factor structure and sub-dimensions. A structure related to the scale was defined according to the items' factor loads, eigenvalues, and the common variance of the measured variable collected due to EFA. In order to perform EFA, the adequacy of the data for the analysis was first examined with Kaiser-Meyer-Olkin (KMO) Measure of Sampling Adequacy and Bartlett's Test of Sphericity. To decide on the sample size's adequacy, a KMO value of at least 0,70 was accepted as the criterion, and The Bartlett Test result was also considered significant as the data set was suitable for multivariate normal distribution (Ntoumanis, 2001). In the EFA, the lower limit for factor loads was set at 0,40 (Tekindal, 2009). 
For the structure validity of the scale dualistically, Confirmatory Factor Analysis (CFA) was performed on the same data structure to obtain evidence for the validity of the structure determined as a result of EFA and determine the consistency of the observed structure with the data. The $t$ values of the items achieved from CFA were examined at the 0.05 significance level. Model-data fit was decided based on fit indices; chi-square/degree of freedom $\left(X^{2} / d f\right)$, root means square error of approximation (RMSEA), standardized root mean square residual (SRMR), comparative fit index (CFI), normed fit index (NFI) and non-normed fit index (NFI) were investigated.

Moreover, to decide the reliability of the data collection tool, item analysis (item-total correlation, the difference between the lower-upper group averages) and internal consistency coefficients (Cronbach's $\alpha$, McDonald's $\boldsymbol{\omega}$ ) techniques were utilized. IBM SPSS Statistics 24.0, Jamovi 1.6.13, and LISREL 8.80 package software were used for data analysis.

\section{Results}

Prior to the scale's validity and reliability analyses, whether the scale scores showed normal distribution was checked by estimating the skewness and kurtosis coefficients and examining the normal q-q plot. For the normal distribution, the graph's value points should not deviate from the normal distribution line, and the skewness and kurtosis coefficients should be between -1.0 and +1.0 (Huck, 2012). As a result of the analysis, it was revealed that the skewness coefficient was -0.444 and the coefficient of kurtosis was 0.232 . It was observed that the values in the $\mathrm{q}-\mathrm{q}$ plot did not deviate excessively and it was determined that the scores obtained from the scale showed a normal distribution. After that, whether the data were appropriate for EFA was examined to determine the construct validity.

\section{Exploratory Factor Analysis}

In order to understand whether the number of participants is adequate for factor analysis or not $\mathrm{KMO}$ was utilised and to understand whether the measurement tool could be decomposed into factor structures, Bartlett's Test was conducted. For factor analysis, the KMO value should be at least 0.60 and Bartlett's test should be significant (Pallant, 2016). As a result of the analysis (Table 1), it was determined that the KMO value was 0.88 and Bartlett's sphericity test was statistically significant $\left(X^{2}{ }_{(990)}=8073.56\right.$; $\mathrm{p}<0.001)$. According to the results, it was understood that the sample size was suitable for factor analysis, and the measurement tool could be divided into factor structures, and EFA was started. 
Table 1

KMO Measure of Sampling Adequacy and Bartlett's Test of Sphericity Results

\begin{tabular}{llc}
\hline KMO & & .882 \\
\hline \multirow{3}{*}{ Bartlett's } & Approx. Chi-Square & 8073.56 \\
& df & 990 \\
& Sig. & .000 \\
\hline
\end{tabular}

EFA is a statistical technique that allows the determination of the dimensionality of the scale and detection of cross-loadings (correlations of variables with multiple factors). Besides, it is instrumental in developing scales or tests (Fletcher, 2007). Through EFA, several observed variables are taken, and the covariances between them are used to describe a smaller set of latent variables to explain their interdependency (Finch, Immekus \& French, 2016). In the present study, the eigenvalues, scree plot, and difference between the variances explained by the factors were examined to determine the number of factors. When the scree plot was concerned, it was seen that the slope turned horizontal from the 10th factor (Figure 1).

\section{Figure 1}

Scree Plot of the 45 Items for SEIPP

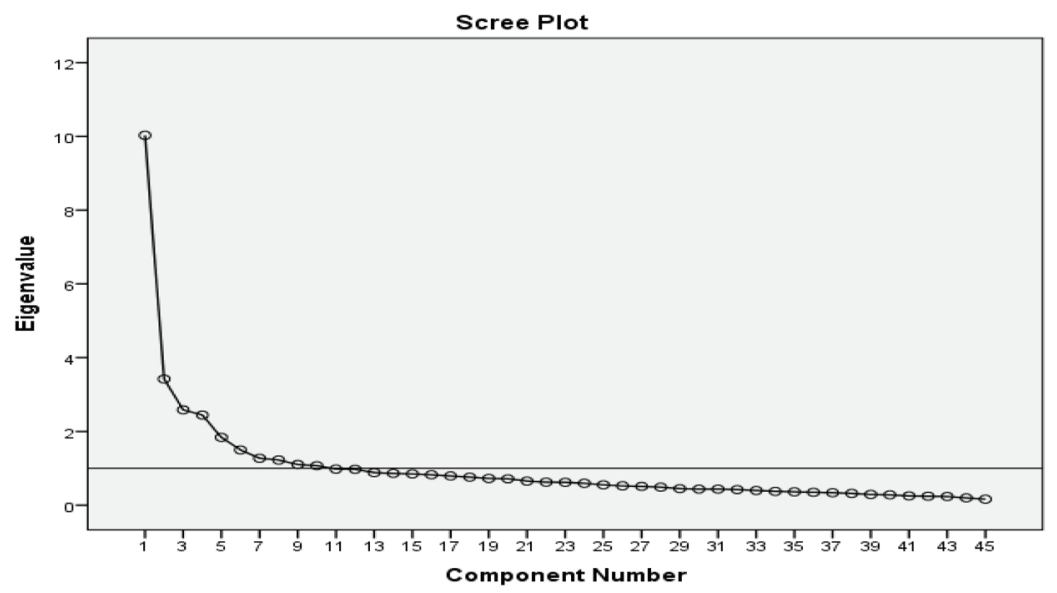

It was determined that the eigenvalues of the factors ranged from 1.07 to 10.02. Besides, the total variance explained by these factors together was $58.87 \%$ (Table 2). When Table 2 was examined, a suggestion for the factor number of the scale is presented under the column titled "Extraction Sums of Squared Loadings". Since there are ten components with eigenvalues above 1, ten factors were proposed for EFA to be realized. According to Çokluk, Şekercioğlu and Büyüköztürk (2012), a vital issue to be considered when deciding on the factor number of the scale is the importance of the contribution of each factor to the total variance. When the variance percentages of the scale's components 
were examined, it was seen that this ratio varied between $22.28 \%$ and $2.72 \%$ for the first eight components and fell below $2.50 \%$ in the other two components. In other words, it was understood that the contribution of the last two components to the total variance was low. In this case, considering the theoretical structure determined during the development of the scale, it was decided by the researchers to repeat the analysis for eight factors.

\section{Table 2}

Total Variance Explained

\begin{tabular}{ccccccc}
\hline \multirow{2}{*}{$\begin{array}{c}\text { Compo- } \\
\text { nent }\end{array}$} & \multicolumn{3}{c}{ Initial Eigenvalues } & \multicolumn{3}{c}{ Extraction Sums of Squared Loadings } \\
\cline { 2 - 6 } & Total & \% of Variance & Cumulative \% & Total & \% of Variance & Cumulative \% \\
\hline 1 & 10.02 & 22.28 & 22.28 & 10.02 & 22.28 & 22.28 \\
2 & 3.42 & 7.60 & 29.88 & 3.42 & 7.60 & 29.88 \\
3 & 2.58 & 5.73 & 35.62 & 2.58 & 5.73 & 35.62 \\
4 & 2.44 & 5.42 & 41.05 & 2.44 & 5.42 & 41.05 \\
5 & 1.84 & 4.09 & 45.14 & 1.84 & 4.09 & 45.14 \\
6 & 1.50 & 3.33 & 48.47 & 1.50 & 3.33 & 48.47 \\
7 & 1.27 & 2.83 & 51.30 & 1.27 & 2.83 & 51.30 \\
8 & 1.22 & 2.72 & 54.03 & 1.22 & 2.72 & 54.03 \\
9 & 1.10 & 2.45 & 56.48 & 1.10 & 2.45 & 56.48 \\
10 & 1.07 & 2.38 & 58.87 & 1.07 & 2.38 & 58.87 \\
\hline
\end{tabular}

Afterwards, EFA was repeated, but this time, eight were written in the relevant section as the number of factors, and varimax was chosen from the orthogonal rotation methods. As a result of the analysis, it was seen that the contribution of the eight factors determined to the variance varied between $3.19 \%$ and $12.38 \%$, and the total contribution of the factors to the variance was $54.03 \%$ (Table 3).

\section{Table 3}

\section{Total Variance Explained}

\begin{tabular}{cccc}
\hline Component & Total & \% of Variance & Cumulative \% \\
\hline 1 & 5.57 & 12.38 & 12.38 \\
2 & 3.98 & 8.84 & 21.23 \\
3 & 3.07 & 6.84 & 28.07 \\
4 & 2.95 & 6.57 & 34.64 \\
5 & 2.86 & 6.37 & 41.01 \\
6 & 2.79 & 6.21 & 47.22 \\
7 & 1.62 & 3.61 & 50.84 \\
8 & 1.43 & 3.19 & 54.03 \\
\hline
\end{tabular}


Through EFA, suitable and unsuitable items are determined, the correlation between variables is examined, and some items are removed from the scale (DeVellis, 2017; Tabachnick \& Fidell, 2014). It is expected that the factor load of an eligible item will be 0.45 or above. However, for a scale with a small number of items, this value can be reduced to 0.30 (Büyüköztürk, 2011). In the current study, a lower limit of 0.40 was adopted for the item factor load value (Tekindal, 2009). Another point that should be considered in selecting items is that an item does not have a high load value in more than one factor; that is, there are no cross-loading items in the scale. The difference between a load of an item on a factor and the highest load after this value should be at least 0.10 (Büyüköztürk, 2011). Also, at least two items should be included in a factor (Akçay, Akçay \& Hekim-Bozkurt, 2020). Two items (items 4 and 6) with a factor load value of less than 0.40 and four cross-loading items (items 19, 21, 32, and 42) were excluded from the scale in line with the criteria in question for determining appropriate items. Item extraction was carried out one by one and starting from the item with the lowest factor load. The researchers named the factors on the scale after the item extraction process. The total explained variance of the scale, which consists of 8 factors and 39 items, was $57.37 \%$, and the contribution of factors to the common variance was $13.41 \%, 9.67 \%, 6.61 \%, 6.59 \%$, $6.41 \%, 6.41 \%, 4.9 \%$, and $3.96 \%$, respectively. The names of the factors obtained from the remaining 39 items, the factor pattern of the scale, and the items' factor load values are presented in Table 4.

\section{Table 4}

Results from Exploratory Factor Analysis

\begin{tabular}{|c|c|c|c|c|c|c|c|c|c|}
\hline \multirow{2}{*}{\multicolumn{2}{|c|}{$\begin{array}{l}\text { SEIPP Item* } \\
1\end{array}$}} & \multicolumn{8}{|c|}{ Factor loading } \\
\hline & & 1 & 2 & 3 & 4 & 5 & 6 & 7 & 8 \\
\hline \multicolumn{10}{|c|}{ Factor 1: Gladness } \\
\hline 7. & $\begin{array}{l}\text { I can communicate healthily with my teachers } \\
\text { in the distance instruction process. }\end{array}$ & .78 & .09 & .18 & .16 & -.06 & .17 & -.02 & .06 \\
\hline 2. & $\begin{array}{l}\text { I am glad about the teaching of the lessons I } \\
\text { take through distance instruction. }\end{array}$ & .72 & .19 & .15 & .07 & .10 & .14 & .15 & .08 \\
\hline 11. & $\begin{array}{l}\text { The distance instruction process positively } \\
\text { affected my thoughts about the learning envi- } \\
\text { ronment (student-centred, individual learning, } \\
\text { inquiry-based, collaborative, etc.). }\end{array}$ & .70 & .08 & .15 & .05 & .12 & .06 & .09 & .06 \\
\hline 8. & $\begin{array}{l}\text { I can communicate healthily with my friends } \\
\text { during the distance instruction process. }\end{array}$ & .70 & -.01 & .22 & .13 & .01 & .03 & -.03 & -.10 \\
\hline 9. & $\begin{array}{l}\text { I can express my thoughts effectively in live lec- } \\
\text { tures conducted through distance instruction. }\end{array}$ & .70 & .14 & .29 & .10 & .03 & .06 & -.01 & .14 \\
\hline 10. & $\begin{array}{l}\text { The distance instruction process has positively } \\
\text { influenced my thoughts about my learning } \\
\text { process. }\end{array}$ & .69 & .17 & .08 & .05 & .09 & .12 & .20 & .11 \\
\hline
\end{tabular}




\begin{tabular}{llllllllll}
\hline & \multicolumn{1}{c}{ SEIPP Item* } & \multicolumn{7}{c}{ Factor loading } \\
\cline { 3 - 9 } & \multicolumn{1}{c}{$\mathbf{1}$} & $\mathbf{1}$ & $\mathbf{2}$ & $\mathbf{3}$ & $\mathbf{4}$ & $\mathbf{5}$ & $\mathbf{6}$ & $\mathbf{7}$ & $\mathbf{8}$ \\
\hline 3. & $\begin{array}{l}\text { I look forward to participating in distance live } \\
\text { lessons. }\end{array}$ & $\mathbf{. 6 6}$ & .14 & -.11 & .09 & .09 & .13 & .19 & .16 \\
\begin{tabular}{l} 
1. $\quad \begin{array}{l}\text { I think I learned the subjects that were pro- } \\
\text { cessed in the distance instruction process. }\end{array}$ \\
\cline { 2 - 8 }
\end{tabular} & $\mathbf{. 6 2}$ & .16 & .29 & .06 & -.01 & .07 & .11 & .21 \\
\end{tabular}

\section{Factor 2: Precaution}

45. Administrators at my school adhere to precau- $\quad .02$ tions related to COVID-19.

44. Teachers at my school adhere to precautions .05 related to COVID-19. 40. The school administration monitors whether
students comply with COVID-19 precautions.

41. Teachers monitor whether students comply with COVID-19 precautions.

43. Students at my school adhere to precautions related to COVID-19.

18. At my school, safety precautions related to COVID-19 are adequate.

Factor 3: Accessibility

38. I can easily access the technologies required for distance instruction (mobile phone, tablet, computer).

37. I can easily access the internet connection required for distance instruction.

5. I quickly use the technologies necessary for distance instruction.

30. I participated in distance instruction activities during the pandemic through live lectures.

\section{Factor 4: Expectation}

13. In the process of back-to-school, I feel a sufficient sense of commitment to the school.

15. After the process of back-to-school, I would like to continue my education in a hybrid model.

25. I can be more successful at school with hybrid instruction.

12. I would be happy to start face-to-face instruction.

14. In the process of back-to-school, I feel a sufficient sense of commitment to my friends.

17. I believe that schools will open fully to face-to- .05 face instruction.

\section{Factor 5: Evaluation}

26. Distance instruction is more motivating than .06 face-to-face instruction. 


\begin{tabular}{|c|c|c|c|c|c|c|c|c|c|}
\hline \multirow{2}{*}{\multicolumn{2}{|c|}{$\begin{array}{l}\text { SEIPP Item* } \\
1\end{array}$}} & \multicolumn{8}{|c|}{ Factor loading } \\
\hline & & \multirow{2}{*}{$\begin{array}{c}1 \\
.05\end{array}$} & \multirow{2}{*}{$\begin{array}{c}2 \\
.04\end{array}$} & \multirow{2}{*}{$\begin{array}{c}3 \\
-.03\end{array}$} & \multirow{2}{*}{$\begin{array}{c}4 \\
.05\end{array}$} & \multirow{2}{*}{$\begin{array}{l}5 \\
.66\end{array}$} & \multirow{2}{*}{$\begin{array}{c}6 \\
-.06\end{array}$} & \multirow{2}{*}{$\begin{array}{c}7 \\
-.01\end{array}$} & \multirow{2}{*}{$\begin{array}{c}8 \\
.21\end{array}$} \\
\hline 20. & $\begin{array}{l}\text { My communication with the teacher in live } \\
\text { lessons is more qualified than in face-to-face } \\
\text { classes. }\end{array}$ & & & & & & & & \\
\hline 22. & $\begin{array}{l}\text { In live lessons, the in-class discussion envi- } \\
\text { ronment is more effective than in face-to-face } \\
\text { classes. }\end{array}$ & .17 & .13 & -.03 & .04 & .64 & -.12 & -.10 & .10 \\
\hline 31. & $\begin{array}{l}\text { I want courses to continue this year with dis- } \\
\text { tance instruction only. }\end{array}$ & .07 & -.18 & .10 & -.27 & .43 & .21 & .10 & .08 \\
\hline 16. & $\begin{array}{l}\text { I had trouble getting used to face-to-face in- } \\
\text { struction during the process of back-to-school. }\end{array}$ & -.24 & -.01 & -.03 & -.21 & .42 & .15 & .09 & -.29 \\
\hline \multicolumn{10}{|c|}{ Factor 6: Support } \\
\hline 36. & $\begin{array}{l}\text { I get psychological support from my teachers at } \\
\text { school during the distance instruction process. }\end{array}$ & .06 & .11 & .09 & .06 & -.19 & .77 & .16 & .09 \\
\hline 33. & $\begin{array}{l}\text { I get psychological support from my family } \\
\text { during the distance instruction process. }\end{array}$ & .18 & .11 & .04 & .10 & -.02 & .75 & -.06 & -.03 \\
\hline 35. & $\begin{array}{l}\text { I get technological support from my teachers at } \\
\text { school during the distance instruction process. }\end{array}$ & .10 & .14 & .05 & .02 & .05 & .65 & .07 & .03 \\
\hline 34. & $\begin{array}{l}\text { I get academic support from my family during } \\
\text { the distance instruction process. }\end{array}$ & .17 & .17 & .27 & .07 & .03 & .62 & .03 & .09 \\
\hline \multicolumn{10}{|c|}{ Factor 7: EBA TV \& Support Points } \\
\hline 29. & $\begin{array}{l}\text { I participated in distance instruction activities } \\
\text { during the pandemic from TV broadcasts. }\end{array}$ & .12 & .12 & .11 & -.04 & -.13 & .05 & .69 & .22 \\
\hline 27. & $\begin{array}{l}\text { In the distance instruction process, EBA TV } \\
\text { broadcasts contribute to my learning about the } \\
\text { relevant subject. }\end{array}$ & .41 & .11 & .05 & .03 & .06 & .06 & .54 & .02 \\
\hline 28. & $\begin{array}{l}\text { In the distance instruction process, EBA TV } \\
\text { broadcasts are enough for me to learn the } \\
\text { relevant subject. }\end{array}$ & .18 & .11 & .04 & .18 & .40 & -.04 & .53 & -.18 \\
\hline 39. & I utilize EBA support points. & .12 & .18 & -.04 & .15 & .15 & .30 & .44 & .04 \\
\hline \multicolumn{10}{|c|}{ Factor 8: Time } \\
\hline 24. & $\begin{array}{l}\text { After distance instruction courses, the time } \\
\text { I spend doing homework, repeating courses, } \\
\text { research, etc., is more than face-to-face classes. }\end{array}$ & .18 & -.01 & .08 & .14 & .17 & .07 & .20 & .70 \\
\hline 23. & $\begin{array}{l}\text { I spend more time preparing for distance } \\
\text { instruction courses than face-to-face courses. }\end{array}$ & .22 & .06 & .11 & .01 & .21 & .10 & .00 & .68 \\
\hline
\end{tabular}

*Unvalidated translation. The scale was developed in Turkish. Using the scale in different languages should be re-evaluated in terms of its reliability and validity.

\section{Confirmatory Factor Analysis}

At this stage, CFA was performed to verify the structure determined by EFA. CFA is a structural equation modeling (SEM) based approach and is used to evaluate how well the actual data fit the specified model (DeVellis, 2017). While SEM is a more general and statistically more complex procedure that includes both factor and regression analysis 
(Geisinger, 2003), CFA is a particular type of factor analysis. CFA, which replaces old methods for determining the validity of a structure, is used to test whether the structure's dimensions are consistent with the researcher's understanding of its nature (Awang, 2012). In order to determine whether the model tested in CFA fits, $X^{2}$ and some other fit indices are checked. There is no single fit index that is universally optimal for each analysis (Finch, Immekus \& French, 2016). There are quite a few fit indices in structural equation modeling, and there are different views about which fit index should be used. In the current research, the most frequently used ones in the literature were used. The path diagram of the model obtained as a result of CFA was presented in Figure 3.

\section{Figure 3}

Path Diagram of the SEIPP

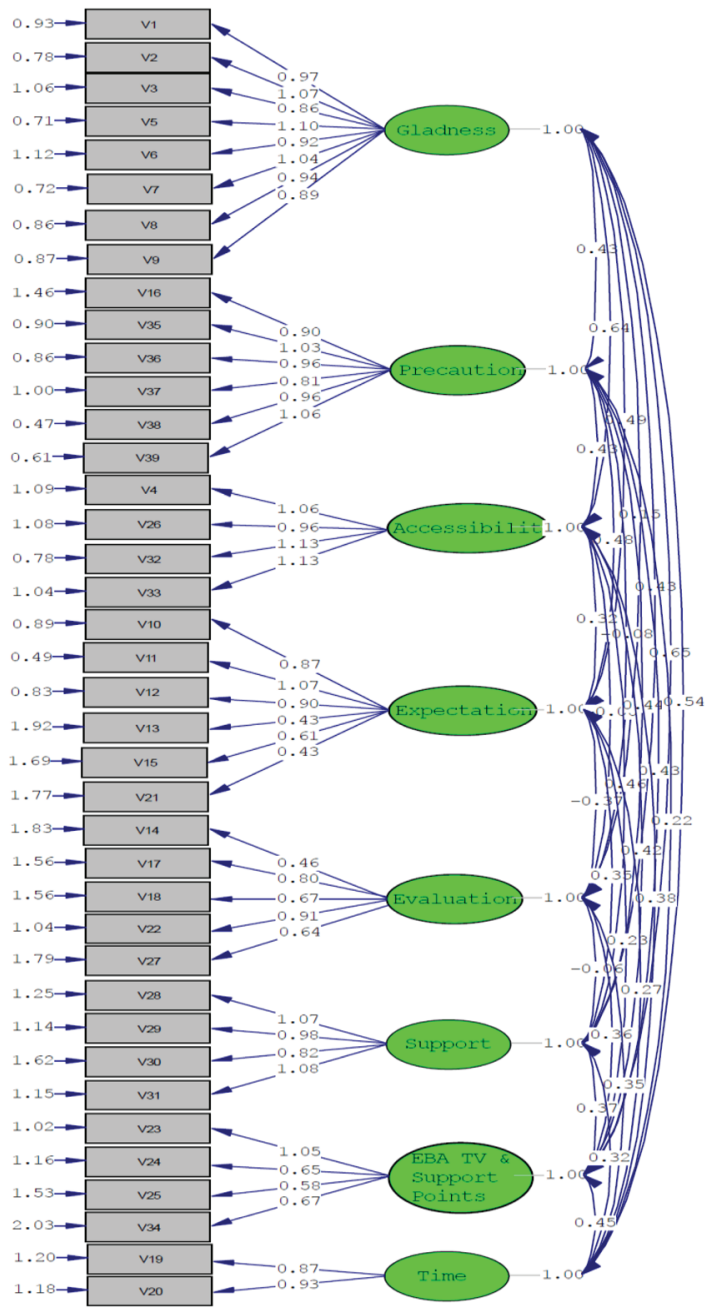


$T$-values were the first to be checked when examining CFA results. The $t$ value for the cases where the latent variables explain the observed values is significant at the level of 0.05 if it exceeds 1.96 and at the level of 0.01 if it exceeds 2.56 (Çokluk et al., 2012). In the CFA model obtained for the SEIPP, it was observed that the $t$ values of the items varied between 5.77 and 19.87 (Table 5). Thus, it was determined that all $t$ values related to the items were significant at the 0.01 level. The error variances of the indicators were checked after this process. It was seen from the "Standardized Solution" path diagram that the error variances of the observed variables were between 0.30 and 0.91 (Table 5). It was concluded that no item should be excluded from the analysis since there were no excessively high values among the error variances for the variables and the $t$ values of all items were significant. After this stage, the next step was to examine the modification proposals and fit indices.

Table 5

CFA Estimates for 8-Factor Model

\begin{tabular}{|c|c|c|c|c|c|c|}
\hline Item & Estimate & S.E. & $t$-value & $p$ & Error Variance & $R^{2}$ \\
\hline 1 & .97 & .05 & 16.61 & 0.00 & .50 & .50 \\
\hline 2 & 1.07 & .05 & 18.60 & 0.00 & .41 & .59 \\
\hline 3 & .86 & .05 & 14.56 & 0.00 & .59 & .41 \\
\hline 4 & 1.06 & .06 & 15.97 & 0.00 & .49 & .51 \\
\hline 5 & 1.10 & .05 & 19.49 & 0.00 & .37 & .63 \\
\hline 6 & .92 & .06 & 14.98 & 0.00 & .57 & .43 \\
\hline 7 & 1.04 & .05 & 18.74 & 0.00 & .40 & .60 \\
\hline 8 & .94 & .05 & 16.75 & 0.00 & .49 & .51 \\
\hline 9 & .89 & .05 & 15.98 & 0.00 & .52 & .48 \\
\hline 10 & .87 & .05 & 14.90 & 0.00 & .54 & .46 \\
\hline 11 & 1.07 & .05 & 19.59 & 0.00 & .30 & .70 \\
\hline 12 & .90 & .05 & 15.65 & 0.00 & .50 & .50 \\
\hline 13 & .43 & .07 & 5.86 & 0.00 & .91 & .08 \\
\hline 14 & .46 & .07 & 5.77 & 0.00 & .90 & .10 \\
\hline 15 & .61 & .07 & 8.61 & 0.00 & .82 & .18 \\
\hline 16 & .90 & .06 & 13.10 & 0.00 & .64 & .36 \\
\hline 17 & .80 & .08 & 10.04 & 0.00 & .71 & .29 \\
\hline 18 & .67 & .07 & 8.70 & 0.00 & .78 & .22 \\
\hline 19 & .87 & .08 & 10.54 & 0.00 & .61 & .39 \\
\hline 20 & .93 & .08 & 10.80 & 0.00 & .58 & .42 \\
\hline 21 & .43 & .07 & 6.05 & 0.00 & .91 & .09 \\
\hline
\end{tabular}




\begin{tabular}{ccccccc}
\hline Item & Estimate & $\boldsymbol{S} . \boldsymbol{E}$. & $\boldsymbol{t}$-value & $\boldsymbol{p}$ & Error Variance & $\boldsymbol{R}^{\mathbf{2}}$ \\
\hline $\mathbf{2 2}$ & .91 & .07 & 12.47 & 0.00 & .55 & .45 \\
$\mathbf{2 3}$ & 1.05 & .07 & 14.01 & 0.00 & .48 & .52 \\
$\mathbf{2 4}$ & .65 & .06 & 9.92 & 0.00 & .73 & .27 \\
$\mathbf{2 5}$ & .58 & .07 & 7.96 & 0.00 & .82 & .18 \\
$\mathbf{2 6}$ & .96 & .06 & 15.05 & 0.00 & .54 & .46 \\
$\mathbf{2 7}$ & .64 & .08 & 7.92 & 0.00 & .81 & .19 \\
$\mathbf{2 8}$ & 1.07 & .07 & 14.52 & 0.00 & .52 & .48 \\
$\mathbf{2 9}$ & .98 & .06 & 14.16 & 0.00 & .54 & .46 \\
$\mathbf{3 0}$ & .82 & .07 & 10.88 & 0.00 & .71 & .29 \\
$\mathbf{3 1}$ & 1.08 & .07 & 15.00 & 0.00 & .49 & .51 \\
$\mathbf{3 2}$ & 1.13 & .06 & 18.30 & 0.00 & .38 & .62 \\
$\mathbf{3 3}$ & 1.13 & .06 & 16.87 & 0.00 & .45 & .55 \\
$\mathbf{3 4}$ & .67 & .08 & 7.97 & 0.00 & .82 & .18 \\
$\mathbf{3 5}$ & 1.03 & .06 & 17.24 & 0.00 & .46 & .54 \\
$\mathbf{3 6}$ & .96 & .05 & 16.66 & 0.00 & .48 & .52 \\
$\mathbf{3 7}$ & .81 & .05 & 14.00 & 0.00 & .60 & .40 \\
$\mathbf{3 8}$ & .96 & .04 & 19.87 & 0.00 & .34 & .66 \\
$\mathbf{3 9}$ & 1.06 & .05 & 19.58 & 0.00 & .35 & .65 \\
\hline
\end{tabular}

There were many modification suggestions in the output file created by the analysis software due to the CFA. However, it has been decided to realize two modifications that will make the largest contribution to $X^{2}$. Accordingly, modifications were made between V36 - V35 and V39 - V38, which are in the same factor. As a result of the CFA, the fit index values of the scale estimated before and after the modification and the cutoff criteria were presented in Table 5.

The first examined fit index was $X^{2} \cdot X^{2}$ is a classical index of fit (Brown, 2015) and a statistic that is evaluated not by itself but by proportion to the degree of freedom ( $d f$ ). For large samples, the ratio of $X^{2} / \mathrm{df}$ below 3 indicates a perfect, while below 5 indicates a medium-level fit (Kline, 1994; Sümer, 2000). When examined in Table 5, it was seen that the $X^{2} / \mathrm{df}$ ratio estimated for the current scale has a perfect fit. Another questioned fit index was the root mean square error of the approach (RMSEA), which tests the reasonably good fit of the tested model in the population (Harrington, 2009). A RMSEA value less than 0,08 corresponds to a good fit, and a value less than 0,05 corresponds to a perfect fit (Browne \& Cudeck, 1992; Sümer, 2000). It was seen that the RMSEA value estimated for the scale corresponded to a good fit. 
Table 6

Scale Fit Indicies and Cutoff Criteria

\begin{tabular}{lccl}
\hline $\begin{array}{c}\text { Goodness-of- } \\
\text { fit indices }\end{array}$ & $\begin{array}{c}\text { Before } \\
\text { modification }\end{array}$ & $\begin{array}{c}\text { After } \\
\text { modification }\end{array}$ & \multicolumn{1}{c}{ Cutoff criteria* } \\
\hline$X^{2} / \mathrm{df}$ & 2.57 & 2.29 & $\begin{array}{l}X^{2} / \mathrm{df} \leq 3 \text { perfect fit } \\
X^{2} / \mathrm{df} \leq 5 \text { good fit }\end{array}$ \\
RMSEA & 0.06 & 0.054 & $\begin{array}{l}\text { RMSEA } \leq .05 \text { perfect fit } \\
\text { RMSEA } \leq .08 \text { good fit } \\
\text { SRMR } \leq .05 \text { perfect fit }\end{array}$ \\
SRMR & 0.067 & 0.065 & $\begin{array}{l}\text { SRMR } \leq .08 \text { good fit } \\
\text { CFI } \geq .95 \text { perfect fit }\end{array}$ \\
CFI & 0.94 & 0.95 & $\begin{array}{l}\text { CFI } \geq .90 \text { good fit } \\
\text { NFI } \geq .95 \text { perfect fit }\end{array}$ \\
NFI & 0.91 & 0.92 & $\begin{array}{l}\text { NFI } \geq .90 \text { good fit } \\
\text { NNFI } \geq .95 \text { perfect fit } \\
\text { NNFI } \geq .90 \text { good fit }\end{array}$ \\
NNFI & 0.94 & 0.95 & .
\end{tabular}

^ Based on Browne \& Cudeck (1992), Hu \& Bentler (1999) and Sümer (2000).

As seen in Table 5, the SRMR index, which is the mean discrepancy between the correlations observed in the input matrix and the correlations predicted by the model (Brown, 2015), was estimated as 0,065 as a result of CFA. This value also corresponded to a good fit. The other fit indices examined in the CFA scope were as follows: CFI was 0.95, NFI was 0.92 and NNFI was 0.95 . While the results of CFI and NNFI fit indices indicate a perfect fit, the NFI fit index's result corresponds to a good fit (Hu \& Bentler, 1999; Sümer, 2000). As a result, we can say that a good fit was obtained with the proposed fit indices.

\section{Reliability Analyses}

After the validity studies of the scale, reliability studies were started. Reliability is the power of a scale item to measure the property it wants to measure, free from random errors (Erkuş, 2014). First, internal consistency coefficients were calculated for the reliability analysis of the scale. Cronbach's alpha was used in the analysis, which is the most commonly used reliability coefficient (Ntoumanis, 2001; Şeker \& Gençdoğan, 2006). The internal consistency coefficient should be as close to 1 as possible. A high Cronbach alpha value means high reliability or low error variance, and it is interpreted that the items are consistent with each other and measure the same property (Tezbaşaran, 2008; Tourangeau, Maitland, Steiger \& Yan, 2020). The acceptable lower limit of this value is 0.60 (DeVellis, 2017; Dörnyei, 2010). When Table 6 was examined, it was seen that the Cronbach's alpha internal consistency coefficient for the scale was at a very good level $(\alpha=.893)$. Still, this coefficient was slightly below the acceptable limit for three subdimensions. 
Table 7

Scale Reliability Statistics

\begin{tabular}{lcc}
\hline \multicolumn{1}{c}{ Dimensions } & McDonald's $\boldsymbol{\omega}$ & Cronbach's $\boldsymbol{\alpha}$ \\
\hline Gladness & 0.896 & 0.893 \\
Precaution & 0.865 & 0.860 \\
Accessibility & 0.821 & 0.818 \\
Expectation & 0.735 & 0.713 \\
Evaluation & 0.605 & 0.591 \\
Support & 0.751 & 0.747 \\
EBA TV \& Support Points & 0.602 & 0.584 \\
Time & 0.581 & 0.581 \\
Total Scale & 0.900 & 0.893 \\
\hline
\end{tabular}

For examining internal consistency in multi-dimensional structures, it is suggested to estimate McDonald's omega (McDonald, 2011) coefficient along with Cronbach's alpha analysis (Dunn, Baguley \& Brunsden, 2014). The omega internal consistency coefficient of the scale was found to be very good $(\boldsymbol{\omega}=.900)$, similar to the alpha coefficient. However, it was determined that the omega coefficients for all sub-dimensions except one were also above the acceptable limit. The fact that the time dimension's omega coefficient remains slightly below the acceptable limit $\left(\right.$ Time $_{\omega}=.581$ ) is thought to be due to the presence of only two items in this sub-dimension.

After determining the internal consistency coefficients, item analysis processes were started in the second stage, and item-total correlations were examined. Item total correlation is the correlation value between an item and the item totals in the sub-dimension. A correlation value of less than 0.1 is weak, between 0.1 and 0.3 is modest, between 0.3 and 0.5 is moderate, when it is between 0.5 and 0.8 is strong, and above 0.8 indicates a very strong relationship (Humble, 2020). When the total correlation values of 39 items in the scale were examined, it was seen that only the correlation value $(r=.22)$ for the 14th item had a modest relationship (Table 7). However, since the factor load, $t$ value, error variance, and statistical significance of the item in question were within acceptable limits, it was decided to keep the item on the scale.

For the item discrimination, the total item scores are ranked in descending order, and the scores in the lower and upper $27 \%$ slices are taken, and the difference between the mean scores of these two groups is analyzed with the $t$-test. The statistically significant difference between the averages is seen as evidence of the internal consistency of the scale (Büyüköztürk, 2011). 


\section{Table 8}

Result of Item Analysis and Item-Total Correlations

\begin{tabular}{|c|c|c|c|c|c|c|c|}
\hline \multirow[t]{2}{*}{ Items* } & \multicolumn{2}{|c|}{$\begin{array}{l}\text { Upper } \\
\text { Group }\end{array}$} & \multicolumn{2}{|c|}{$\begin{array}{l}\text { Lower } \\
\text { Group }\end{array}$} & \multirow[t]{2}{*}{$t$} & \multirow[t]{2}{*}{$p$} & \multirow{2}{*}{$\begin{array}{l}\text { Item-Total } \\
\text { Correlation }\end{array}$} \\
\hline & $\bar{X}$ & $S d$ & $\bar{X}$ & $S d$ & & & \\
\hline $\begin{array}{l}\text { I think I learned the subjects that were pro- } \\
\text { cessed in the distance instruction process. }\end{array}$ & 4.31 & 0.88 & 2.05 & 1.19 & 16.76 & 0.000 & 0.66 \\
\hline $\begin{array}{l}\text { I am glad about the teaching of the lessons I } \\
\text { take through distance instruction. }\end{array}$ & 4.45 & 0.92 & 2.03 & 1.10 & 18.50 & 0.000 & 0.73 \\
\hline $\begin{array}{l}\text { I look forward to participating in distance } \\
\text { live lessons. }\end{array}$ & 4.46 & 0.81 & 2.50 & 1.21 & 14.75 & 0.000 & 0.60 \\
\hline $\begin{array}{l}\text { I quickly use the technologies necessary for } \\
\text { distance instruction. }\end{array}$ & 4.45 & 1.04 & 2.41 & 1.41 & 12.81 & 0.000 & 0.61 \\
\hline $\begin{array}{l}\text { I can communicate healthily with my teachers } \\
\text { in the distance instruction process. }\end{array}$ & 4.54 & 0.81 & 2.30 & 1.24 & 16.58 & 0.000 & 0.76 \\
\hline $\begin{array}{l}\text { I can communicate healthily with my friends } \\
\text { during the distance instruction process. }\end{array}$ & 4.33 & 1.04 & 2.58 & 1.42 & 10.91 & 0.000 & 0.61 \\
\hline $\begin{array}{l}\text { I can express my thoughts effectively in live lec- } \\
\text { tures conducted through distance instruction. }\end{array}$ & 4.52 & 0.83 & 2.30 & 1.19 & 16.71 & 0.000 & 0.72 \\
\hline $\begin{array}{l}\text { The distance instruction process has positively } \\
\text { influenced my thoughts about my learning } \\
\text { process. }\end{array}$ & 4.04 & 1.10 & 1.94 & 0.98 & 15.64 & 0.000 & 0.68 \\
\hline $\begin{array}{l}\text { The distance instruction process positively } \\
\text { affected my thoughts about the learning } \\
\text { environment (student-centered, individual } \\
\text { learning, inquiry-based, collaborative, etc.). }\end{array}$ & 3.96 & 1.06 & 2.02 & 1.07 & 14.10 & 0.000 & 0.65 \\
\hline I would be happy to start face-to-face instruction. & 4.73 & 0.79 & 3.73 & 1.61 & 6.12 & 0.000 & 0.52 \\
\hline $\begin{array}{l}\text { In the process of back-to-school, I feel a suffi- } \\
\text { cient sense of commitment to the school. }\end{array}$ & 4.68 & 0.70 & 3.25 & 1.52 & 9.31 & 0.000 & 0.63 \\
\hline $\begin{array}{l}\text { In the process of back-to-school, I feel a suf- } \\
\text { ficient sense of commitment to my friends. }\end{array}$ & 4.50 & 1.00 & 3.25 & 1.46 & 7.76 & 0.000 & 0.52 \\
\hline $\begin{array}{l}\text { After the process of back-to-school, I would } \\
\text { like to continue my education in a hybrid } \\
\text { model. }\end{array}$ & 3.73 & 1.45 & 2.74 & 1.45 & 5.24 & 0.000 & 0.33 \\
\hline $\begin{array}{l}\text { I had trouble getting used to face-to-face in- } \\
\text { struction during the process of back-to-school. }\end{array}$ & 2.00 & 1.31 & 2.43 & 1.59 & -2.26 & 0.025 & 0.22 \\
\hline $\begin{array}{l}\text { I believe that schools will open fully to face- } \\
\text { to-face instruction. }\end{array}$ & 4.13 & 1.29 & 3.08 & 1.48 & 5.87 & 0.000 & 0.37 \\
\hline $\begin{array}{l}\text { At my school, safety precautions related to } \\
\text { COVID-19 are adequate. }\end{array}$ & 4.46 & 1.02 & 2.44 & 1.52 & 12.09 & 0.000 & 0.55 \\
\hline $\begin{array}{l}\text { My communication with the teacher in live } \\
\text { lessons is more qualified than in face-to-face } \\
\text { classes. }\end{array}$ & 2.79 & 1.59 & 2.19 & 1.48 & 3.03 & 0.003 & 0.42 \\
\hline In live lessons, the in-class discussion envi- & 2.84 & 1.54 & 2.16 & 1.29 & 3.72 & 0.000 & 0.34 \\
\hline
\end{tabular}

ronment is more effective than in face-to-face classes. 


\begin{tabular}{|c|c|c|c|c|c|c|c|}
\hline \multirow[t]{2}{*}{ Items* } & \multicolumn{2}{|c|}{$\begin{array}{l}\text { Upper } \\
\text { Group }\end{array}$} & \multicolumn{2}{|c|}{$\begin{array}{l}\text { Lower } \\
\text { Group }\end{array}$} & \multirow[t]{2}{*}{$t$} & \multirow[t]{2}{*}{$p$} & \multirow{2}{*}{$\begin{array}{l}\text { Item-Total } \\
\text { Correlation }\end{array}$} \\
\hline & $\bar{X}$ & $S d$ & $\bar{X}$ & $S d$ & & & \\
\hline $\begin{array}{l}\text { I spend more time preparing for distance } \\
\text { instruction courses than face-to-face courses. }\end{array}$ & 3.57 & 1.30 & 2.21 & 1.26 & 8.23 & 0.000 & 0.41 \\
\hline $\begin{array}{l}\text { After distance instruction courses, the time } \\
\text { I spend doing homework, repeating courses, } \\
\text { research, etc., is more than face-to-face classes. }\end{array}$ & 3.87 & 1.28 & 2.40 & 1.43 & 8.37 & 0.000 & 0.41 \\
\hline $\begin{array}{l}\text { I can be more successful at school with hybrid } \\
\text { instruction. }\end{array}$ & 3.83 & 1.29 & 2.86 & 1.52 & 5.36 & 0.000 & 0.35 \\
\hline $\begin{array}{l}\text { Distance instruction is more motivating than } \\
\text { face-to-face instruction. }\end{array}$ & 2.28 & 1.48 & 1.98 & 1.31 & 1.71 & 0.088 & 0.48 \\
\hline $\begin{array}{l}\text { In the distance instruction process, EBA TV } \\
\text { broadcasts contribute to my learning about } \\
\text { the relevant subject. }\end{array}$ & 3.94 & 1.24 & 1.93 & 1.14 & 13.09 & 0.000 & 0.48 \\
\hline $\begin{array}{l}\text { In the distance instruction process, EBA TV } \\
\text { broadcasts are enough for me to learn the } \\
\text { relevant subject. }\end{array}$ & 2.78 & 1.40 & 1.73 & 1.11 & 6.44 & 0.000 & 0.35 \\
\hline $\begin{array}{l}\text { I participated in distance instruction activities } \\
\text { during the pandemic from TV broadcasts. }\end{array}$ & 3.36 & 1.46 & 2.19 & 1.09 & 7.00 & 0.000 & 0.33 \\
\hline $\begin{array}{l}\text { I participated in distance instruction activities } \\
\text { during the pandemic through live lectures. }\end{array}$ & 4.77 & 0.66 & 2.73 & 1.55 & 13.20 & 0.000 & 0.58 \\
\hline $\begin{array}{l}\text { I want courses to continue this year with dis- } \\
\text { tance instruction only. }\end{array}$ & 2.45 & 1.68 & 1.89 & 1.37 & 2.82 & 0.005 & 0.30 \\
\hline $\begin{array}{l}\text { I get psychological support from my family } \\
\text { during the distance instruction process. }\end{array}$ & 4.29 & 1.26 & 2.57 & 1.50 & 9.63 & 0.000 & 0.56 \\
\hline $\begin{array}{l}\text { I get academic support from my family during } \\
\text { the distance instruction process. }\end{array}$ & 4.37 & 1.06 & 2.50 & 1.36 & 11.86 & 0.000 & 0.52 \\
\hline $\begin{array}{l}\text { I get technological support from my teachers at } \\
\text { school during the distance instruction process. }\end{array}$ & 3.35 & 1.55 & 1.93 & 1.22 & 7.93 & 0.000 & 0.46 \\
\hline $\begin{array}{l}\text { I get psychological support from my teachers at } \\
\text { school during the distance instruction process. }\end{array}$ & 3.73 & 1.47 & 2.13 & 1.28 & 8.97 & 0.000 & 0.62 \\
\hline $\begin{array}{l}\text { I can easily access the internet connection } \\
\text { required for distance instruction. }\end{array}$ & 4.45 & 0.92 & 2.56 & 1.51 & 11.70 & 0.000 & 0.70 \\
\hline $\begin{array}{l}\text { I can easily access the technologies required } \\
\text { for distance instruction (mobile phone, tablet, } \\
\text { computer). }\end{array}$ & 4.32 & 1.12 & 2.55 & 1.52 & 10.26 & 0.000 & 0.67 \\
\hline I utilize EBA support points. & 3.37 & 1.69 & 1.78 & 1.21 & 8.40 & 0.000 & 0.32 \\
\hline $\begin{array}{l}\text { The school administration monitors whether } \\
\text { students comply with COVID-19 precautions. }\end{array}$ & 4.63 & 0.84 & 2.63 & 1.48 & 12.88 & 0.000 & 0.70 \\
\hline $\begin{array}{l}\text { Teachers monitor whether students comply } \\
\text { with COVID-19 precautions. }\end{array}$ & 4.66 & 0.81 & 2.98 & 1.59 & 10.28 & 0.000 & 0.65 \\
\hline $\begin{array}{l}\text { Students at my school adhere to precautions } \\
\text { related to COVID- } 19 \text {. }\end{array}$ & 4.25 & 0.96 & 2.72 & 1.38 & 9.98 & 0.000 & 0.59 \\
\hline $\begin{array}{l}\text { Teachers at my school adhere to precautions } \\
\text { related to COVID- } 19 \text {. }\end{array}$ & 4.85 & 0.51 & 3.34 & 1.43 & 10.88 & 0.000 & 0.72 \\
\hline $\begin{array}{l}\text { Administrators at my school adhere to precau- } \\
\text { tions related to COVID- } 19 \text {. }\end{array}$ & 4.82 & 0.55 & 3.21 & 1.60 & 10.43 & 0.000 & 0.72 \\
\hline
\end{tabular}


For the SEIPP, the averages of the total scores of 120 participants in the lower and upper $27 \%$ slice were compared using the $t$-test. It was determined that 38 of the $p$ values in Table 7 were significant at the level of 0.01 and the $p$-value for the 22nd item was statistically non-significant. Similarly, since the factor load, error variance, and item-total correlation of this item were within acceptable limits, it was decided to keep the scale's 22nd item.

\section{Discussion and Conclusion}

When the literature is examined, many surveys evaluate the teaching process during the pandemic period. Still, to our knowledge, no scale has yet been developed for determining the opinions of middle and high school students about instruction during the pandemic process. Considering this point, the study aimed to develop a scale allowing middle and high school students to determine their opinions on distance instruction (TV broadcast, live lecture) during the COVID-19 pandemic period, hybrid instruction (distance and face-to-face instruction), and the new normal back-to-school process. The research was carried out on 442 students at secondary and high school levels in Diyarbakır, Giresun, and Bayburt.

It was determined that there were no missing values or outliers in the data set of the study, and the data showed normal distribution. It was concluded that the KMO value estimated to test the suitability of the data to factor analysis was .88, and Bartlett's test was statistically significant. According to Ntoumanis (2001), the KMO result above 0.70 indicates that the sample size is sufficient for factor analysis. The significant Bartlett test result indicates that the data set is adequate for multivariate normal distribution.

EFA and CFA were performed to determine the construct validity of the scale. According to the result of the EFA, the scale consists of eight sub-dimensions called: (1) Gladness; (2) Precaution; (3) Accessibility; (4) Expectation; (5) Evaluation; (6) Support; (7) EBA TV \& Support Points; and (8) Time which have an eigenvalue above 1. The number of items on the scale decreased to 39 by removing six items with low or cross-loadings. The variances of the sub-dimensions are $13.41 \%, 9.67 \%, 6.61 \%, 6.59 \%, 6.41 \%, 6.41 \%, 4.9 \%$ and $3.96 \%$, respectively, and the total variance explained by the eight sub-dimensions is $57.37 \%$. The total variance explained to be between $40 \%$ and $60 \%$ is considered sufficient (Büyüköztürk, 2011). The factor loading values of the items vary between 0.421 and 0.820 . The fact that all factor loadings of the items in the scale are above the lower limit of 0.40 (Tekindal, 2009) shows that the items are consistent with their structure.

While the results of the $t$-test between the lower and upper groups for item discrimination were significant at 0.01 level for 38 items, the test result for one item was statistically non-significant. The Cronbach's alpha and McDonald's omega coefficients estimated to determine the scale's internal reliability coefficient were found as 0.893 and 0.900 , respectively. The internal consistency coefficients of the scales that consist of high correlation 
items with each other are also high. The reliability coefficient that can be considered sufficient on a Likert-type scale should be close to 1 (Tezbaşaran, 2008). According to DeVellis (2017), if the internal reliability coefficients calculated for the scales are below 0.60 , it is unacceptable. If they are between 0.60 and 0.65 , it is undesirable. If they are between 0.65 and 0.70 , it is minimally acceptable. If they are between 0.70 and 0.80 , it is respectable. It is very good if internal reliability coefficients are between 0.80 and 0.90 , and if they are well above 0.90 , one should consider shortening the scale. Regarding the classification in question, it was concluded that the internal reliability values estimated for the broad-scale were very good. It indicates that the scale does not contain spelling errors, incomprehensible and inhomogeneous questions, and mistakes in the scoring process, and the scale is not of sufficient length. It can be said that SEIPP developed in this context can be evaluated in the category of highly reliable scales (Seçer, 2013).

CFA also confirmed the eight-factor structure determined by EFA. In the CFA model obtained for the SEIPP, it was concluded that the $t$ values of the items varied between 5.77 and 19.87. According to Çokluk et al. (2012), $t$ values for all items of the scale which exceed 2.56 show that the results obtained are significant at 0.01 . Besides, the error variances of the observed variables of the scale vary between 0.30 and 0.91 . According to this result, the error variance is not high in any of the scale items. Of the fit indices estimated as a result of CFA; $\mathrm{X}^{2} / \mathrm{df}(=2.29<3)$, CFI $(=.95 \geq .95)$ and NNFI $(=.95 \geq$ $.95)$ were found to show a perfect fit, RMSEA $(=.054<.08)$, SRMR $(=.065<.08)$ and NFI (= .92> .90) show a good fit (Browne \& Cudeck, 1992; Sümer, 2000). This situation enabled the model tested with CFA to be accepted.

The high score obtained from the scale or sub-dimensions indicates that the student's opinions about the teaching in the pandemic process in the relevant dimension are positive. A low score is an indicator of negative student opinions. The total scores obtained from the scale can be used to determine the students' views on distance, face-to-face, and hybrid instruction activities during the pandemic process, as well as the sub-dimensions of the scale can be used independently from each other. Based on the results obtained from the validity and reliability analysis of the SEIPP, it can be said that the scale is valid and reliable.

The results of this study show that the developed scale can be used as a valid and reliable measurement tool by researchers who want to study on back to school after pandemic and crisis periods. Considering the existence of future public health and safety concerns, this and similar scale studies are deemed necessary in education. As a matter of fact, multi-dimensional planning is needed to create both distance education and a hybrid learning environment efficiently (Xiao et al., 2020). Therefore, all education stakeholders should be taken into account with their needs (Koruyucu \& Kabak, 2020). The scale developed within the research scope can determine students' needs, who are one of the essential stakeholders of education. Therefore, the scale can be applied by teachers, school administrators, researchers, and policymakers who want to determine 
how students evaluate the instruction in the pandemic and their opinions on this process. Researchers can conduct qualitative research to examine scale results in more depth to gain more information about instruction activities in the pandemic and the subsequent back-to-school period. Besides, it may be suggested to use this scale again in similar crisis periods after making necessary validity and reliability analyses.

\section{References}

Adnan, M., \& Anwar, K. (2020). Online learning amid the COVID-19 pandemic: Students' perspectives. Journal of Pedagogical Sociology and Psychology, 2(1), 45-51. doi:10.33902/ JPSP.2020261309

Akçay, D., Akçay, B. D., \& Hekim-Bozkurt, Ö. (2020). Çocuklarda uyku bozukluğu ölçeğinin Türkçe güvenilirliği ve geçerliliği [Reliability and validity of Turkish sleep disturbance scale for children]. Anatolian Journal of Psychiatry, 21, 70-77. doi:10.5455/apd.65084

Alawamleh, M., Al-Twait, L. M., \& Al-Saht, G. R. (2020). The effect of online learning on communication between instructors and students during Covid-19 pandemic. Asian Education and Development Studies. doi:10.1108/AEDS-06-2020-0131

Anadolu Agency (2020). Kovid-19 salgını dünya genelinde uzaktan ve sanal eğitimi zorunlu $k_{1} l_{1}$ [The Covid-19 outbreak has made remote and virtual education mandatory worldwide]. Retrieved February 02, 2021, from https://www.aa.com.tr/tr/egitim/kovid-19-salgini-dunyagenelinde-uzaktan-ve-sanal-egitimi-zorunlu-kildi/1814237

Aucejo, E. M., French, J., Araya, M. P. U., \& Zafar, B. (2020). The impact of COVID-19 on student experiences and expectations: Evidence from a survey. Journal of Public Economics, 191. doi:10.1016/j.jpubeco.2020.104271

Awang, Z. (2012). Structural equation modeling using AMOS graphic. Shah Alam: Universiti Teknologi MARA Publication Centre (UPENA).

Aydın, Ç. G. (2020). COVID-19 salgını süresinde öğretmenler [Teachers during the Covid-19 outbreak]. TEDMEM. Retrieved October 28, 2020, from https://tedmem.org/covid-19/covid19-salgini-surecinde-ogretmenler

Barton, D. C. (2020). Impacts of the COVID-19 pandemic on field instruction and remote teaching alternatives: Results from a survey of instructors. Academic Practice In Ecology And Evolution, 10, 12499-12507. doi:10.1002/ece3.6628

Bozkurt, A. (2020). Koronavirüs (Covid-19) pandemi süreci ve pandemi sonrası dünyada eğitime yönelik değerlendirmeler: Yeni normal ve yeni eğitim paradigması [Coronavirus (Covid-19) pandemic process and evaluations for education in the post-pandemic world: New normal and new education paradigm]. Açıöğretim Uygulamaları ve Araştırmaları Dergisi, 6(3), 112-142.

Brom, C., Lukavský, J., Greger, D., Hannemann, T., Straková, J., \& Švaříček, R. (2020). Mandatory home education during the COVID-19 lockdown in the Czech Republic: A rapid survey of 1st-9th graders' parents. Frontiers in Education, 5(103). doi:10.3389/feduc.2020.00103 
Brown, T. A. (2015). Confirmatory factor analysis for applied research. New York: The Guilford Press.

Browne, M. W., \& Cudeck, R. (1992). Alternative ways of assessing model fit. Sociological Methods \& Research, 21(2), 230-258. doi:10.1177/0049124192021002005

Büyüköztürk, Ş. (2011). Sosyal bilimler için veri analizi el kitabı [Data analysis handbook for social sciences]. Ankara: Pegem Akademi.

Can, E. (2020). Coronavirüs (Covid-19) pandemisi ve pedagojik yansımaları: Türkiye'de açık ve uzaktan eğitim uygulamaları [Coronavirus (Covid-19) pandemic and pedagogical implications: Open and distance education applications in Turkey]. Açıköğretim Uygulamaları ve Araştırmaları Dergisi, 6(2), 11-53.

Chang, D. G., Park, J. B., Baek, G. H., Kim, H. J., Bosco, A., Hey, H. W. D., \& Lee, C. K. (2020). The impact of COVID-19 pandemic on orthopaedic resident education: A nationwide survey study in South Korea. International Orthopaedics, 44(11), 2203-2210. doi:0.1007/s00264-020-04714-7

Çokluk, Ö., Şekercioğlu, G., \& Büyüköztürk, Ş. (2012). Sosyal bilimler için çok değişkenli istatistik: SPSS ve LISREL uygulamaları [Multivariate statistics for social sciences: SPSS and LISREL applications]. Ankara: Pegem Akademi.

Demuyakor, J. (2020). Coronavirus (COVID-19) and online learning in higher institutions of education: A survey of the perceptions of Ghanaian international students in China. Online Journal of Communication and Media Technologies, 10(3), e202018. doi:10.29333/ojcmt/8286

DeVellis, R. F. (2017). Scale development: Theory and applications. California: Sage.

Dong, C., Chao, S., \& Li, H. (2020). Young children's online learning during COVID-19 pandemic: Chinese parents' beliefs and attitudes. Children and Youth Services Review, 118. doi:10.1016/j. childyouth.2020.105440

Dörnyei, Z. (2010). Questionnaires in second language research: Construction, administration, and processing. New York: Routledge.

Dunn, T. J., Baguley, T., \& Brunsden, V. (2014). From alpha to omega: A practical solution to the pervasive problem of internal consistency estimation. British Journal of Psychology, 105(3), 399-412. doi:10.1111/bjop.12046.

Erkuş, A. (2014). Psikolojide ölçme ve ölçek geliştirme I: Temel kavramlar ve işlemler [Measurement and scale development in psychology I: Basic concepts and procedures]. Ankara: Pegem Akademi.

Essilfie, A. A., Hurley, E. T., Strauss, E. J., \& Alaia, M. J. (2020). Resident, fellow, and attending perception of e-learning during the COVID-19 pandemic and implications on future orthopaedic education. Journal of the American Academy of Orthopaedic Surgeons, 28(19). doi:10.5435/JAAOS-D-20-00579

Finch, W. H., Immekus, J. C., \& French, B. F. (2016). Applied psychometrics using SPSS and AMOS. Charlotte: IAP.

Fletcher, T. D. (2007). Factor analysis. In S. G. Rogelberg (Ed.), Encyclopedia of industrial and organizational psychology (pp. 243-246). California: Sage. 
Gable, R. K., \& Wolf, M. B. (1993). Instrument development in the affective domain: Measuring attitudes and values in corporate and school settings. New York: Springer.

Garbe, A., Ogurlu, U., Logan, N., \& Cook, P. (2020). COVID-19 and remote learning: Experiences of parents with children during the pandemic. American Journal of Qualitative Research, 4(3), 45-65. doi:10.29333/ajqr/8471

Geisinger, K. F. (2003). Testing and assessment in cross-cultural psychology. In J. R. Graham \& J. A. Naglieri (Eds.), Handbook of psychology: Volume 10 assessment psychology (pp. 95-118). New Jersey: John Wiley \& Sons.

Gökmen, Ö. F., Duman, İ., \& Horzum, M. B. (2016). Uzaktan eğitimde kuramlar, değişimler ve yeni yönelimler [Theories, changes and new directions in distance education]. Açıkögretim Uygulamaları ve Araştırmaları Dergisi, 2(3), 29-51.

Guo, T., Kiong, K. L., Yao, C. M., Windon, M., Zebda, D., Jozaghi, Y., ... \& Hanna, E. Y. (2020). Impact of the COVID-19 pandemic on Otolaryngology trainee education. Head \& Neck, 42(10), 2782-2790. doi:10.1002/hed.26368

Harrington, D. (2009). Confirmatory factor analysis. New York: Oxford University Press.

$\mathrm{Hu}, \mathrm{L} .$, \& Bentler, P. M. (1999). Cutoff criteria for fit indexes in covariance structure analysis: Conventional criteria versus new alternatives. Structural Equation Modeling: A Multidisciplinary Journal, 6(1), 1-55, doi:10.1080/10705519909540118

Huck, S. W. (2012). Reading statistics and research. Boston: Pearson.

Humble, S. (2020). Quantitative analysis of questionnaires: Techniques to explore structures and relationships. New York: Routledge.

Karakaya, F., Adıüzzel, M., Üçüncü, G., Çimen, O., \& Yilmaz, M. (2020). Teachers' views towards the effects of Covid-19 pandemic in the education process in Turkey. Participatory Educational Research, 8(2), 17-30. doi:10.17275/per.21.27.8.2

Kline, P. (1994). An easy guide to factor analysis. New York: Routledge.

Kline, P. (2015). A handbook of test construction: Introduction to psychometric design. New York: Routledge.

Korucu, A. T., \& Kabak, K. (2020). Türkiye' de hibrit öğrenme uygulamaları ve etkileri: Bir meta analiz çalışması [Hybrid learning practices and effects in Turkey: A meta analysis study]. Bilgi ve İletişim Teknolojileri Dergisi, 2(2), 88-112.

Liu, S., Zhang, H., Ye, Z., \& Wu, G. (2020). Online blending learning model of school-enterprise cooperation and course certificate integration during the COVID-19 epidemic. Science, 8(2), 66-70. doi:10.11648/j.sjedu.20200802.16

Mailizar, Almanthari, A., Maulina, S., \& Bruce, S. (2020). Secondary school mathematics teachers' views on E-learning implementation barriers during the COVID-19 pandemic: The case of Indonesia. Eurasia Journal of Mathematics, Science and Technology Education, 16(7), em1860. doi:10.29333/ejmste/8240

Marinoni, G., Van't Land, H., \& Jensen, T. (2020). The impact of Covid-19 on higher education around the world. IAU Global Survey Report. Paris: International Association of Universities. McDonald, R. P. (2011). Test theory: A unified treatment. New York: Routledge. 
Merfeldaitė, O., Prakapas, R., \& Railienė, A. (2020). Nuotolinio mokymo organizavimas COVID-19 metu: Bendrojo ugdymo mokyklų patirtis [Challenges of distance teaching during COVID-19: The experience of general education schools]. Pedagogika, 140(4), 5-17. doi:10.15823/p.2020.140.1

Ministry of National Education (2020a). Bakan Selçuk, koronavirüs'e karşı eğitim alanında alınan tedbirleri açıkladı [Minister Selçuk announced the measures taken in the field of education against coronavirus]. Retrieved January 01, 2020, from https://www.meb.gov.tr/bakan-selcukkoronaviruse-karsi-egitimalaninda-alinan-tedbirleri-acikladi/haber/20497/tr

Ministry of National Education (2020b). Yüz yüze eğitimde ikinci aşama başladı, milyonlarca öğrenci okullarıyla buluştu [The second phase of face-to-face education has started, millions of students met with their schools]. Retrieved December 16, 2020, from https://www.meb. gov.tr/yuz-yuze-egitimde-ikinci-asama-basladi-milyonlarca-ogrenci-okullariyla-bulustu/ haber/21787/tr

Moore, M. (1990). Background and overview of contemporary American distance education. New York: Pergamon.

Ntoumanis, N. (2001). A step-by-step guide to SPSS for sport and exercise studies. London: Routledge.

Pallant, J. (2016). SPSS Survival manual: A step by step guide to data analysis using IBM SPSS. Berkshire: McGraw-Hill.

Panorama Education. (2020). Back-to-school surveys for distance/hybrid learning. Retrieved October 12, 2020, from https://www.panoramaed.com/back-to-school-surveys

Paudel, P. (2021). Online education: Benefits, challenges and strategies during and after COVID-19 in higher education. International Journal on Studies in Education, 3(2), 70-85.

Puntis, J. W. (2020). Is it really time to go back to school? Archives of Disease in Childhood, 106. doi:10.1136/archdischild-2020-319911

Rajmil, L. (2020). Role of children in the transmission of the COVID-19 pandemic: A rapid scoping review. BMJ Paediatrics Open, 4(1). doi:10.1136/ bmjpo-2020-000722

Robbins, J. B., England, E., Patel, M. D., DeBenedectis, C. M., Sarkany, D. S., Heitkamp, D. E., ... \& Jordan, S. G. (2020). COVID-19 impact on well-being and education in radiology residencies: A survey of the association of program directors in radiology. Academic Radiology, 27(8), 1162-1172. doi:10.1016/j.acra.2020.06.002

Seçer, İ. (2013). SPSS ve LISREL ile pratik veri analizi [Practical data analysis with SPSS and LISREL]. Ankara: Anı Yayıncılık.

Shahrvini, B., Baxter, S. L., Coffey, C. S., MacDonald, B. W., \& Lander, L. (2021). Pre-clinical remote undergraduate medical education during the COVID-19 pandemic: A survey study. BMC Medical Education, 21, 13. doi:10.1186/s12909-020-02445-2

Shawaqfeh, M. S., Al Bekairy, A. M., Al-Azayzih, A., Alkatheri, A. A., Qandil, A. M., Obaidat, A. A., ... \& Muflih, S. M. (2020). Pharmacy students perceptions of their distance online learning experience during the Covid-19 pandemic: A cross-sectional survey study. Journal of Medical Education and Curricular Development, 7, 1-9. doi:10.1177/2382120520963039 
Sümer, N. (2000). Yapısal eşitlik modelleri: Temel kavramlar ve örnek uygulamalar [Structural equation models: Basic concepts and sample applications]. Turkish Psychological Review, 3(6), 49-74.

Şeker, H., \& Gençdoğan, B. (2006). Psikoloji ve eğitimde ölçme aracı geliştirme [Developing measurement tools in psychology and education]. Ankara: Nobel Yayın.

Tabachnick, B. G., \& Fidell, L. S. (2014). Using multivariate statistics. Essex: Pearson.

Tamburlini, G., \& Marchetti, F. (2020). Covid-19 pandemia: Reasons and indications for reopening education services. Medico e Bambino, 39, 301-4.

Tay, L., \& Jebb, A. (2017). Scale development. In S. Rogelberg (Ed), The SAGE encyclopedia of industrial and organizational psychology. California: Sage.

TEDMEM (2020). COVID-19 ve dünyada okulların durumu [COVID-19 and the state of schools in the world]. Retrieved December 16, 2020, from https://tedmem.org/covid-19/covid-19-vedunyada-okullarin-durumu

Tekindal, S. (2009). Duyuşsal özelliklerin ölçülmesi için araç oluşturma [Generating tools for measuring affective characteristics]. Ankara: Pegem Akademi.

Tezbaşaran, A. A. (2008). Likert tipi ölçek hazırlama kılavuzu [Likert type scale preparation guide]. Ankara: Türk Psikologlar Derneği Yayınları.

Tourangeau, R., Maitland, A., Steiger, D., \& Yan, T. (2020). A framework for making decisions about question evaluation methods. In P. C. Beatty et al. (Eds.), Advances in questionnaire design, development, evaluation, and testing (pp. 47-74). New Jersey: Wiley.

UNESCO (2020). COVID-19 educational disruption and response. Paris: UNESCO. Retrieved October 17, 2020, from https://en.unesco.org/covid19/educationresponse

Xiao, J., Sun-Lin, H. Z., Lin, T. H., Li, M., Pan, Z., \& Cheng, H. C. (2020). What makes learners a good fit for hybrid learning? Learning competences as predictors of experience and satisfaction in hybrid learning space. British Journal of Educational Technology. doi:10.1111/bjet.12949

Woodland, L., Smith, L. E., Amlot, R., Rubin, A., Webster, R. K., Wessely, S., \& Rubin, G. J. (2020). Parents' willingness to send children back to school during the COVID-19 pandemic: A cross-sectional survey. Available at SSRN 3675426. doi:10.2139/ssrn.3675426

Yıldırım, A., \& Şimşek, H. (2011). Sosyal bilimlerde nitel araştırma yöntemleri [Qualitative research methods in the social sciences]. Ankara: Seçkin Yayıncılık.

Yilmaz-İnce, E., Kabul, A., \& Diler, İ. (2020). Distance education in higher education in the COVID-19 pandemic process: A case of Isparta Applied Sciences University. International Journal of Technology in Education and Science (IJTES), 4(4), 343-351.

Yamamoto, G. T., \& Altun, D. (2020). Coronavirüs ve çevrimiçi (online) eğitimin önlenemeyen yükselişi [The coronavirus and the rising of online education]. Journal of University Research, 3(1), 25-34. doi:10.26701/uad.711110 


\title{
Mokymo vertinimo skalè pandemijos procese: plètra, pagristumas ir patikimumas
}

\author{
Özgür Tutal $^{1}$, Bünyami Kayalı ${ }^{2}$, Mehmet Yavuz $^{3}$, Mehmet Hasançebi ${ }^{4}$, Funda Yeşildağ-Hasançebi ${ }^{5}$ \\ Nacionaliné švietimo ministerija, TUR-21070Dijarbakyras, Turkija, ozgurtutal@windowslive.com \\ Baiburto universitetas, Technikos mokslų profesinè mokykla, TUR-69000 Baiburtas, Turkija, bunyami_kayali@ \\ hotmail.com \\ 3 Bingolio universitetas, Nuotolinio mokymo ir tyrimų centras, TUR-12000 Bingolis, Turkija, myavuz@bingol.edu.tr, \\ myavuz@bingol.edu.tr \\ Nacionalinè švietimo ministerija, TUR-28000 Giresunas, Turkija, mehmet.hasancebi@outlook.com \\ Giresuno universitetas, Gamtos mokslų katedra, TUR-28000 Giresunas, Turkija, funda.hasancebi@giresun.edu.tr
}

\section{Santrauka}

Tyrimo tikslas - parengti skalę, pagal kurią būtų galima atskleisti mokinių ir studentų nuostatas į nuotolinį mokymą (TV transliacija, tiesioginė pamoka) ir mišrų mokymą (nuotolinis ir kontaktinis mokymas) vidurinių ir aukštųjų mokyklų mokiniams ir studentams grịžtant i mokyklas ir universitetus. Tyrimo dalyviai buvo atrinkti patogiuoju imties būdu. Apklausos duomenys buvo gauti iš 442 mokinių ir studentų, besimokančių Turkijos vidurinėse ir aukštosiose mokyklose. 2020-2021 m. ekspertų apžvalga buvo atlikta turinio pagrịstumui užtikrinti. Siekiant nustatyti skalès struktūros pagrịstumą, buvo atlikta tiriamoji (angl. Exploratory Factor Analysis EFA) ir patvirtinančioji (angl. Confirmatory Factor Analysis CFA) faktorinè analizè. Be to, norint įsitikinti duomenų rinkimo įrankio patikimumu, buvo atlikta elementų analizė (elemento ir visumos koreliacija, skirtumas tarp apatinès ir viršutinės grupės vidurkių) ir ịvertinti vidiniai suderinamumo koeficientai (Cronbacho $\alpha$, McDonaldo $\omega$ ). Remiantis skalès pagrịstumo ir patikimumo analizès rezultatais, galima teigti, kad mokymo vertinimo skalè pandemijos procese (angl. Scale of Evaluating Instruction in Pandemic Process SEIPP) yra pagrịsta ir patikima. Remiantis rezultatu, mokymo vertinimo skale pandemijos procese susideda iš 39 elementų ir aštuonių vadinamųjų subdimensijų: 1) džiaugsmas; 2) atsargumas; 3) prieinamumas; 4) lūkestis; 5) įvertinimas; 6) palaikymas; 7) švietimo informacinis tinklas televizija ( angl. EBA) ir parama; 8) laikas.

Esminiai žodžiai: korona virusas (COVID-19), pandemija, nuotolinis mokymas, grižimas i mokyklą, mišrus mokymas, skalès plètra. 